\title{
Refugees, Rights, and Human Security
}

\author{
Colin J. Harvey
}

\section{Abstract}

This essay explores the connection between discourses of membership, and refugee and human rights law. The argument is that state practice is often anchored in conceptions of democracy that refugee advocates must challenge at a fundamental level. I am particularly interested in the idea of human security. In addition, it is suggested that although human rights law has an essential role to play, we should not neglect the importance of refugee law as a status-granting mechanism. In the end, specific problems in refugee law call for progressive reform. For example, the essay calls for serious engagement with the idea of international or regional regulatory mechanisms to monitor state practice in this area. Many of the ideas applied in domestic contexts, such as the Canadian, come from international discussions. These discussions are often removed from effective participation. If states now function-and construct policy - at this level, then why should we not strongly advocate the creation of systems of accountability that operate at this level also?

\section{Résumé}

Cet article explore la relation entre les discours sur l'appartenance et la loi sur le droit d'asile et les droits de l'homme. Le raisonnement utilisé est que la pratique des états est souvent ancrée dans des concepts de démocratie que les défenseurs du droit d'asile se doivent de remettre en question. Je fais cela en relation avec l'idée de la sécurité humaine. Additionellement, il est suggéré que bien que la loi sur les droits de l'homme ait un rôle essentiel à jouer, nous ne devrions pas négliger l'importance que la loi sur le droit d'asile a à jouer en tant que mécanisme octroyant un statut. En fin de compte, il faudra apporter des réformes progressives touchant aux problèmes spécifiques de la loi sur le droit d'asile. Par exemple, l'article réclame que soit examinée sérieusement l’idée de mécanismes régulateurs au niveau international ou régional pour faire le suivi de la pratique des états dans ce domaine. Un grand nombre d'idées appliquées dans un contexte local - par exemple, dans le contexte canadien - émanent en fait de discussions qui ont eu lieu au niveau international, sans participation effective de ceux qui en sont finalement affectés. Si, à présent, les états fonctionnent et formulent des politiques à ce niveau-là, pourquoi ne devrions-nous pas préconiser vigoureusement la création de systèmes de responsabilité opérant également à ce même niveau.

\section{Introduction}

7 here is a tendency in refugee law to look hopefully to Canada as a model of best practice. To many people in Canada, I have no doubt this might seem odd. There is strong criticism of Canadian law and practice and concern about current proposals. What this optimistic external gaze reflects, I suspect, is a level of desperation among those in Europe who are appalled by state responses to refugees and asylum seekers. Within the European Union (EU), in particular, there exists a culture of the lowest common denominator based on the idea that "If everyone else in Europe is doing it, so can we," or, "We are doing this because it is the European norm." In other words, the focus is limited to other European states only. Anyone who has practical experience of lobbying governments in Europe on asylum law and policy (as I have with the Irish government) will be able to relate to this. In despair one looks for "life beyond Europe," and Canada is usually cited as the place to examine.

In a world still divided into states, the issue of how to address forced displacement is a troubling one. For those who are displaced, legal and political niceties take second place to the immediate need for protection. At the core of this protection is what I term in this essay "human security." The introduction of this term is not a tool to displace rights discourse from refugee protection. Rather it is to forward other values as important in the current debate about the future of refugee law. This has become significant at a time when refugees and asylum seekers, particularly in 
Europe, are being denied basic socio-economic rights. These rights are still not accorded the recognition they deserve. In the United Kingdom (U.K.), the context from which I am writing, this has become a pressing issue, as governments have been willing to erode basic socioeconomic entitlements in a rather crude attempt to discourage asylum seeking. This has included the withdrawal of welfare benefits and now the construction of what can only be described as an experiment in "social engineering" to address the needs of destitute asylum seekers. ${ }^{.}$The process of asylum seeking has been regarded by many governments as problematic. Asylum seekers are "criminalized" and routinely constructed as threats to the internal security of the polity. This is now being supplemented with welfare schemes that aim to make asylum-seeking appear as an increasingly unattractive option.

The institution of asylum, as presently understood, is centred upon those who have managed to cross a border. The focus is primarily on external displacement. This is the main concern of this essay. My aim here is to examine the relationship between refugee and human rights law in the U.K. context. It is now of more general interest, given the decision of the Labour government to incorporate the European Convention on Human Rights 1950 into domestic law. The Human Rights Act 1998 entered into force throughout the U.K. on October 2, 2000. Asylum law is one of those areas where significant case-law is likely to emerge. My intention in this essay is not simply to applaud this overdue development; rather, I want to stress that we require values to assess the impact of human rights law. This is equally applicable in the Canadian context. In refugee law we can talk of refugee protection principles, but I suggest that the concept of human security is significant in not only alerting us to the broad range of values that must be respected, but also the continuing importance of refugee law as a status-granting mechanism. In our understandable rush to embrace what human rights law has to offer, there is reason to remain committed to the core values of refugee protection anchored in an inclusive vision of the 1951 convention. Therefore, while the essay draws upon the U.K. experience, it speaks also to more general debates in refugee law and policy.

\section{Refugee Law, Inclusion/Exclusion, and the Construction of Membership and Belonging}

The world may now be a smaller place for many people. Globalization does not respect borders, and technological developments have radically transformed our understanding of time and space. But can we say this is a development that brings universal benefit to all? We cannot. In practice, the world has in fact become a more tightly regulated public space for the marginalized. For those who do not possess the means, and who do not have the skills required by affluent states, movement is far from free. Refugees and asylum seekers wishing to enter the $\mathrm{EU}$, for example, must overcome ever higher hurdles. These containment practices can all be cloaked in the discourses of root causes and prevention, but the fact remains: for many individuals and groups, movement has never been so difficult as it is now. This cannot be probed in any great depth here. But one might speculate that as loss of autonomy becomes a major anxiety of states, internal security and the regulation of certain types of entry become more important. In a world of risk this is an area where states perhaps believe they can, either individually or collectively, continue to be assertive.

At a time when there is much optimistic talk of a new cosmopolitan world order, or postnational forms of membership and belonging, the response to asylum seekers appears all very familiar. The reason for this goes much deeper than the political will of states. It is tied fundamentally to the principles that are constitutive of democratic polities. While it is easy at the international level to focus on the sheer political will of individual states, one must remain aware of the reasons that states function in this way. There is in fact a basis in understandings of democratic citizenship for state practice. In other words, categories that have progressive implications for some at the national level, notably citizens, can have a negative impact on the treatment of refugees and asylum seekers.

The idea of democratic citizenship remains connected in many societies to the notion of self-determination. In other words, that a political community has the right to dictate the terms of its own governance. There is a long history of republican thought that traces the whole idea of democracy to its core in the right of a community to determine its own future. Rules on membership are a consequence. A political community seeks not only the terms of its own governance, but also to determine who will be included. Rules that regulate membership spring from the concept of internal self-determination.

There are, however, principles that some claim transcend democratic citizenship. In earlier times it was to theology that people looked for a "higher law" above and beyond the state. In our pluralist and secular times, this will no longer do as a rational explanation for values that are centred on personhood and not status. God may well be dead, but now we have international law. International law reflects an expansive vision of human rights that attach to 
the person and not solely to the citizen. This focus can also be found within some systems of constitutional rights protection.

The treatment of asylum seekers brings to the fore a tension between notions of democratic citizenship and "borderless" strains of liberalism that are anchored in the idea that rights attach to the person. One is a vision of a world of states with flourishing democratic polities and membership rules; the other is a blurred vision of free movement and open borders. Many who work in refugee law are understandably tempted by the latter model. It seems to hold out the possibility of a more humane approach to asylum, but it can be illusive. In an international community still largely divided into states, "borderless liberalism" can appear out of touch with the realities of life in democratic societies. And more troubling, it fails to answer the complex issues that arise. My own view is that scholars of refugee law need to engage with work in deliberative democracy in order to sketch an approach that would present a real challenge to the current practices of states. ${ }^{2}$ It would not be anchored solely in arguments about universal human rights and would be prepared to take the idea of a political democracy seriously. Viewed in this way, refugee law continues to be an impressive tool for achieving humanitarian objectives when dealing with the plight of some of the forcibly displaced.

\section{Complementing Refugee Protection?}

The previous section ended with rather an upbeat assessment of the continuing potential of refugee law. This view is not universally shared. In fact, one is more likely to hear reference today to human rights law "coming to the rescue" of refugee law. As is well known, refugee law reflects a particular approach to the idea of protecting the displaced. It is a limited and partial response to a severe international problem. The 1951 Convention relating to the Status of Refugees reflects a compromise between the state imperative of migration control and humanitarian concerns. One can present this rather melodramatically as a legalistic exercise in exclusion, but this is only a partial account.

There are few areas of law that do not include and exclude at precisely the same time. Refugee law would not be the expression of a commitment to an exception to general migration control concerns if it was not in an important sense exclusionary. There are, however, more substantial criticisms of refugee law. I will deal with two here. First, refugee law confines protection to those with a "wellfounded fear of persecution for a Convention reason." As we will see below, human rights law (in the form of the
European Convention on Human Rights) does not limit protection to ill-treatment for a particular convention reason. An extensive jurisprudence has evolved in refugee law around what precisely it means to come within a convention reason. The debates are in essence familiar ones to legal scholars. Some see little reason why refugee law should not be progressively developed and constructively interpreted, while others (more attached to the intention of the drafters) fear that states will simply abandon refugee law entirely if pushed too far. The difficulty for the human rights lawyer is that refugee law has clear limits inscribed in the text of the convention. Creativity can take us far, but often not as far as many would wish to go. The result is the coexistence of a delimited understanding of refugee protection and a body of human rights law that on some occasions goes beyond the protection offered by refugee law.

The second aspect of refugee law often criticized is its exceptions, even to the most vital protections. The obvious example of this is article 33(2), but the exclusion clauses in article 1 can be presented in a similar way. Refugee law contains a concept of the deserving and undeserving person, ${ }^{3}$ of which human rights lawyers tend to be suspicious (although one can question such an approach after the recent response of the human rights community to the General Pinochet case in the U.K.). It is with the exclusion clauses that we can run into difficulties with arguments about constructive interpretation. States now seem prepared to be creative in their application of the exclusion clauses in refugee law, in a way that departs from the specific aims of the provisions. As states become increasingly concerned about their internal security, it is tempting for them to make excessive use of these clauses. Human rights law again can be presented as the solution by prohibiting return in circumstances where it would be permissible in refugee law.

Human rights law clearly has a role to play in complementing refugee protection. But one should also recognize the limitations. The standards that need to be met in human rights law are often higher than in refugee law. In addition, rules that prohibit return seldom deal with the crucial issue of status. The reality is that many individuals and groups are left in a form of legal limbo. The rise of the informal status is one of the key features of the European response to forced displacement. What this does in practice is promote human insecurity. Human rights lawyers should be careful not to promote this culture of deformalization in refugee protection. Status matters to the displaced, and refugee law has the advantage of providing it, with specific entitlements that attach to it. We should not 
abandon the struggle to ensure that full and effective use is made of refugee law as it presently exists. There is much unfinished business in refugee protection.

\section{Refugees, Asylum Seekers, and the U.K.'s Human Rights Act 1998}

If there are lessons from the U.K. context for Canada, then they are primarily warnings about what can go wrong. Problems with the system raise fundamental questions about its practical operation. The latest legislative measure, the Immigration and Asylum Act 1999, follows a line of similar legislation that has fostered a highly distinctive approach to an area that until the 1990s had received little attention from legislators. The other major event, and the focus of this section, is the enactment of the Human Rights Act 1998. This legislation incorporates significant aspects of the European Convention on Human Rights into the domestic law of the U.K. ${ }^{4}$ There was extensive debate on which model of rights enforcement should be adopted. The Canadian model was in the end rejected, and the government opted for a more robust version of the New Zealand model of rights protection. Courts and tribunals in the U.K. are now under an obligation to interpret primary and subordinate legislation, as far as it is possible to do so compatibly with convention rights. ${ }^{5}$ While subordinate legislation can be struck down, the government decided not to give to the courts the same power over primary legislation. On primary legislation the struggles will be over finding interpretations that are compatible with convention rights. There will be occasions, however, when this is impossible. In such circumstances, designated courts are permitted to make a declaration of incompatibility. ${ }^{6} \mathrm{~A}$ declaration of incompatibility does not render the relevant provision invalid, 7 but it may trigger a remedial order procedure whereby Parliament can address the offending provision. ${ }^{8}$ While the government has stated that this is the likely result of a declaration of incompatibility, there is no guarantee that the government will act. What the legislation effectively achieves is a delicate balance between parliamentary democracy and the protection of human rights. The suspicion is that designated courts will strain to find an interpretation that fits with convention rights rather than indulge excessively in declarations of incompatibility. However, at this stage it is difficult to predict how this will map out in practice.

Asylum law is an area where much is expected of the Human Rights Act. The European convention institutions have shown a willingness to develop convention rights to embrace the protection of refugees and asylum seekers.
When interpreting convention rights, courts and tribunals in the U.K. are now obliged to consider the case-law of the convention institutions. ${ }^{9}$ While they are not obliged to follow it, the past approach is likely to be significant. Some of the more important cases are worth considering here, for they demonstrate precisely how human rights law can have an impact on the protection of the displaced, but they also indicate the limits of this area of law and policy.

The case of Soering v. $U K^{10}$ is regarded as one of the more important judgments of the European Court of Human Rights. While this was an extradition case, the implications of the judgment were clear for those seeking to protect asylum seekers. The court held that the U.K. would violate article 3 if it returned the applicant to face the "death row phenomenon" in the U.S. The court, in this case, was only following what was the established jurisprudence of the European Commission of Human Rights. Although the court extended the protection to include asylum seekers, it has always made clear that the state has a right, as a matter of well-established international law, to regulate the entry and deportation of migrants subject to its convention obligations. The court, while prepared to extend the protection to a group not directly referred to in the convention, has been cautious nevertheless. An individual must demonstrate substantial grounds for believing that there is a real risk of article 3 ill-treatment upon return.

The test is a stricter one than that applied in the context of refugee law. This is evident in Vilvarajah $\mathrm{v}$. $U K{ }^{, 1}{ }^{11}$ where the difficulties of bringing a successful article 3 claim were demonstrated. In this case the applicants were Sri Lankan Tamils who had been returned. Their article 3 claim was unsuccessful, even though they had been ill-treated again when sent back. The court held that this was not reasonably foreseeable at the time the U.K. decided to return the applicants. It relied to some extent on the experience of the U.K. authorities in this area and on objective evidence of an improvement in conditions. As to the plight of the applicants, the court concluded that there was nothing to distinguish their cases from others. In addition, the court adopted a generous interpretation of judicial review in the U.K. context in relation to the applicants' article 13 claim. This is not to argue that the court has been unwilling to work at the boundaries of article 3. In Ahmed v. Austria, ${ }^{12}$ the court appeared to have little difficulty with the idea that persecution could emanate from non-state agents, and Chahal v. $U K^{13}$ demonstrated the absolute nature of the article 3 protection. At a time when many states were showing concern about the political activities of asylum seekers, the court made an important intervention by stressing that 
the behaviour of the individual is not a material factor; the exclusive focus is on the risk of ill-treatment upon return. In assessing this risk, the court has emphasized the importance of a rigorous and independent determination process. In Jabari v. Turkey, ${ }^{14}$ the court held that a strict timelimit for excluding asylum claims effectively denied access to a rigorous determination process. This point is also evident in the rather different case of Amuur v. France, ${ }^{15}$ where the court stated that confinement should not "deprive the asylum seeker of the right to gain effective access to the procedure for determining refugee status." ${ }^{16}$ The court held in this case that confinement of the applicants in the international zone, and at an airport hotel, constituted a violation of article 5(1). French law at the time was inadequate, and the guidelines did not permit the domestic courts to intervene effectively.

Article 8 is also relevant to the plight of refugees and asylum seekers. Although there is much discussion of globalization, states continue to be assertive in this area. The state is alive and well in the areas of asylum and immigration law. Human rights law thus assumes an important place in shaping and directing this instinct in humane directions and in some cases preventing the state from acting in the way it wishes to. Article 8 guarantees the right to private and family life. It is often raised in deportation cases where an individual has established family connections. ${ }^{17}$ Deportation becomes an option for states when the individual has been involved in criminal activity, or other action that triggers the process in domestic law. ${ }^{18}$ The European convention has been used to raise rights-based issues in this process; in particular, whether the deportation action is proportionate to the legitimate aim that is pursued by the state. These cases involve difficult balancing exercises, and the jurisprudence of the court is open to some criticism for its lack of clarity. Nevertheless what it reveals is that human rights law can have an impact in an area that many states regard as central to the self-definition of the modern state. In other words, the case-law of the European convention reveals that human rights law can have a practical impact on the treatment of asylum seekers. It is thus a valuable tool in the general struggle to secure refugee protection principles.

The courts in the U.K. have an obligation to take the jurisprudence into account, but there is no requirement that they must follow it. This allows room for the progressive development of convention rights. In the U.K. context, this is likely to have a significant impact on asylum law. The jurisprudence of the convention institutions reveals the impact that human rights law can have. However, it also shows the gap in monitoring at the heart of refugee and asylum law. While there is little doubt that the existing human rights bodies can fulfill a useful function in providing an international form of redress for asylum seekers, it is worth considering a dedicated monitoring mechanism for refugee law. As the UNHCR embarks on a global consultation, it is now time to introduce the idea of international forms of regulation of state practice (I would put it as strongly as that) into the area of refugee law. Human rights law and institutions can, as I have noted, play their part. However, this should not become an excuse to avoid the difficult task of renewing refugee law and practice. In this process of renewal we should not exclude the idea of substantial institutional reform at the international level.

\section{Conclusion}

This is an important time in the debate on refugee law. It is generally accepted that states are pursuing an agenda of restriction. Canada, so often looked to as an example of good practice, seems to be following this depressing international trend. How do we counter this? The challenge is to make use of the existing tools to struggle to secure decent treatment for refugees and asylum seekers, while presenting an alternative narrative to the dominant logic in the international community at present. Human rights law can play a part. The European Convention on Human Rights has been an important tool for asylum seekers in Europe. However, refugee lawyers must fundamentally rethink their own subject in order to ensure not only that it is revitalized but that it is relevant to the changing dynamics of the international community and international forms of regulation. There is a need for sustained dialogue about how this can be achieved. In this dialogue we must be careful to protect what we as refugee lawyers have achieved already, but we should not be afraid to advance models of protection that would guarantee better treatment for the displaced. In particular, there is a pressing need for a form of regulation of national practices that operates at the international or regional level. If anything, this would take the pressure off the human rights mechanisms and ease concerns about the current lack of uniformity in application. Refugee law can be made to work. However, we should not rule out progressive reform. The struggle is to find those willing to act as advocates for a different vision of refugee protection and then to make sure that their voices are heard. The UNHCR has a leading role to play in ensuring that this happens at the national, regional, and international levels. 


\section{Notes}

1. See Colin Harvey, Seeking Asylum in the UK: Problems and Prospects (London: Butterworths, 2000).

2. This point is developed further in Colin Harvey, "Dissident Voices: Refugees, Human Rights and Asylum in Europe," Social and Legal Studies 9 (2000): 367-96.

3. Convention relating to the Status of Refugees, 28 July 1951, 189 UNTs 137, Article 1D-F.

4. Human Rights Act 1998 s. 1(1). Articles 2-12 and 14 of the Convention; Articles 1-3 of the First Protocol; and Articles 1-2 of the Sixth Protocol; as read with Articles 16-18 of the Convention.

5. Ibid., s. 3 .

6. Ibid., s. 4 .

7. Ibid., s. 4(6).

8. Ibid., s. 10.

9. Ibid., s. 2(1).

10. (1989) 11 EHRR 439.

11. (1992) 14 EHRR 1.

12. (1996) 24 EHRR 278.

13. (1996) 23 EHRR 413.

14. Judgment of 11 July 2000.

15. (1996) 22 EHRR 533.

16. Para. 43.

17. See, for example, Beljoudi v. France (1992) 14 EHRR 803; Nasriv. France (1995) 21 EHRR 458; Boughanemi v. France (1996) 22 EHRR 228.

18. It has also been raised in entry cases. See, for example, Gul v. Switzerland (1996) 22 EHRR 93.

Colin J. Harvey is professor of constitutional and human rights law, Department of Law, University of Leeds.

(C) Colin J. Harvey, 2001. This open-access work is licensed under a Creative Commons Attribution-NonCommercial 4.0 International License, which permits use, reproduction and distribution in any medium for non-commercial purposes, provided the original author(s) are credited and the original publication in Refuge: Canada's Journal on Refugees is cited. 